\title{
American Muslim Marital Quality: A Preliminary Investigation
}

\author{
Aliya R. Chapman \\ George Mason University \\ Lauren Bennett Cattaneo
}

George Mason University

\section{Authors' Note}

We are indebted to Mr. Khalid Iqbal for his enthusiasm, his assistance in the compilation of this survey, and for facilitating the recruitment of participants. We also thank Ms. Salma Abugideiri and Dr. Jon Mohr, who provided helpful advice on survey construction, and the leaders of the Muslim community organizations who emailed the survey to their communities.

Correspondence concerning this article should be sent to Dr. Lauren Cattaneo, Department of Psychology, 4400 University Drive, MSN 3F5, Fairfax, Virginia 22030 E-mail: Icattane@gmu.edu

\section{Abstract}

This paper describes the results of an exploratory investigation into American Muslims' marital quality. Respondents were 296 young, well-educated, long-term North American residents, most of whom lived near a major metropolitan hub. They reported generally healthy and satisfying marriages, though women reported lower marital quality than men. Marital problems most commonly included issues with in-laws, family or friends, finances, differing interests, and conflicting attitudes concerning sex. Women were more likely than men to identify in-laws as a source of conflict in the marriage; further research should investigate the nature of this conflict. This information may aid in the development of therapeutic interventions for distressed American Muslim couples that account for unique stressors 
that affect this community, such as the role of extended family and the effect of a community-wide emphasis on intact marriages.

Keywords: American Muslim, marital satisfaction, marital quality, in-laws

The study of marital satisfaction has significant social implications. Failed marriages have negative effects on society and the individual (Carrere, Buehlman, Gottman, Coan, \& Ruckstuhl, 2000), while married individuals (men in particular) experience multiple social, physical, and psychological benefits in comparison to their unmarried or divorced counterparts (Bramlett \& Mosher, 2002; Waite, 2003). Children in divorced and single-parent homes, and even in homes with a step-parent, struggle with greater academic, psychological, social, and behavioral problems than children with two biological parents in the home (Bramlett \& Mosher, 2002).

Unfortunately, even though marriage provides important benefits, marital satisfaction appears elusive for many couples. The Centers for Disease Control and Prevention estimate that 20\% of first marriages in America end in separation or divorce after 5 years, and one-third end after 10 years (Bramlett \& Mosher, 2002). This percentage varies considerably across racial and ethnic categories: for example, $32 \%$ of Caucasian American women's first marriages end by the first decade, compared to $47 \%$ of African American women's first marriages, and $20 \%$ of Asian American women's first marriages (Bramlett \& Mosher, 2002). While this variance may reflect cultural differences in attitudes toward marriage, even communities that value marriage particularly highly and frown upon divorce report concern about their members' marital health. The American Muslim community (Alshugairi, 2010; Beverley, 2002; Curtis, 2010; Ghayyur, 2010; Haddad, Smith, \& Moore, 2006; Leonard, 2003; Siddiqui, 2009), with whom this study is concerned, is an example of a community that is concerned about its members' marriages. ${ }^{1}$

The Need for Information about American Muslim Marital Health

The American Muslim community's concerns are evident in the reports of religious leaders and counselors, who describe growing marital conflict and dissolution among the American Muslims they serve (e.g., Kholoki, 2007, Nadir, 1998, Siddiqui, 2009). Yet the research literature contains little information about the quality of American Muslim marriages (Amer, 2010), including the question of whether the concerns of the community are warranted.

1. For the purpose of this study, the term "American Muslim" refers to individuals who live in North America and identify themselves as followers of the Islamic faith. 


\section{The State of Research}

In the limited amount of research available on marriage in the American Muslim community, there is conflicting evidence about the frequency of divorce. A single study estimates a nationwide American Muslim divorce rate of 32.33\% (Ba-Yunus, 2000, 2007), a high number and one that is contested (Alshugairi, 2010; Leonard, 2003) because of the methodology of the study. Ba-Yunus derived his statistic by examining 10 years of official marriage and divorce records in five American states and one Canadian province selected for their large Muslim populations. He divided the average number of Muslim divorces per state by the average number of Muslim marriages per state, and then averaged the states' mean Muslim divorce rates to yield a "nationwide" statistic of $32.33 \%$ (Ba-Yunus, 2007). This statistic should be considered with caution, not only because of the lack of information about the sample and the non-random selection of states, but also because of the difficulty of obtaining accurate figures for Muslim marriages and divorces. Not all Muslims will document their marriages (or divorces) with their state. Some prefer religious ceremonies to legal ones (Macfarlane, 2012), and others were married in a country outside the United States, so that the only American legal record is of their divorce (Ba-Yunus, 2000).

In contrast to Ba-Yunus' divorce rate of $32.33 \%$, Alshugairi (2010) reported a much-lower divorce rate of $21.3 \%$ for a sample of 751 Californian Muslims. This sample statistic closely matches the above-mentioned ten year divorce rate of Asian American women-an important point, since approximately one-third of American Muslims are South Asian (Bukhari, 2003). Yet it is BaYunus' higher statistic that appears in several mainstream American Muslim publications (e.g. Ghayyur, 2010; Kholoki, 2007; Siddiqui, 2009), despite the lack of consensus over its accuracy. Ba-Yunus' statistic has caused and reflected considerable unrest. Further empirical investigation of American Muslim marriages may help to allay concerns or point toward specific problems that may be investigated in more detail.

\section{The State of Supportive Services}

Investigation of American Muslim marriages is not only needed to clarify the community's concerns about its divorce rate, but also to help develop marital counseling for distressed couples. There is a relative lack of well-informed, culturally-sensitive services for this community. Muslims view marriage as part of their Islamic duty, and consequently put much effort into safeguarding couples' stability and healthy functioning (Alshugairi, 2010). However, couples who attempt to resolve marital disputes may struggle to obtain the necessary support in America. Many distressed Muslim couples seek to follow religious 
teachings that urge spouses to seek mediation from family in times of marital conflict; but immigrant American Muslims may not have easy access to their extended family. Professional marital therapy is an alternative, but studies suggest that American Muslims are reluctant to seek professional help because of concerns about the therapist's cultural and religious competence (Ahmed \& Reddy, 2007; Hodge, 2005). American Muslim couples tend to turn instead to religious leaders for marital counseling (Bagby, Perl, \& Froehle, 2001), but research indicates that less than half of these leaders have formal qualifications in a mental health field (Abu-Ras, Gheith, \& Cournos, 2008; Ali, Milstein, \& Marzuk, 2005). Thus, American Muslims who experience marital problems may have little recourse to trained, culturally-sensitive assistance. Research into the nature and health of American Muslim marriages would inform mental health providers and religious leaders about culturally unique aspects of American Muslim marriages, as well as common problems between American Muslim spouses. In turn, providers' and religious leaders' increased knowledge about American Muslim marriages may improve the quality of interventions in this community.

\section{Current Knowledge about American Muslim Marital Quality}

\section{Marital Satisfaction}

The few existing studies on American Muslim marital quality focus on marital satisfaction, which refers to an individual's "overall appraisal" of contentment with his or her marriage (Kamp Dush, Taylor, \& Kroeger, 2008, p. 212). These studies appear to contradict the community's concern about rising levels of marital discord and divorce: most indicate that American Muslims tend to report moderate to high marital satisfaction (Alshugairi, 2010; Asamarai et al., 2008; Haque \& Davenport, 2009; Shah, 2007). However, women in the larger of these studies reported significantly lower marital satisfaction than men (Alshugairi, 2010; Asamarai et al., 2008). This pattern is also found in the mainstream literature on marital quality, in which the gender difference in marital satisfaction is present across age, generation, and length of marriage (Amato, Johnson, Booth, \& Rogers, 2003; Bulanda, 2011; Corra, Carter, Carter, \& Knox, 2009; Kamp Dush et al., 2008). Researchers often attribute this gender difference to women's lower influence or "say" in the marriage (Steil, 2000). More work is needed to establish the presence of the trend in the American Muslim community.

\section{Marital Conflict}

A broad understanding of marital quality in the American Muslim community requires information on marital conflict as well as satisfaction. One study 
(Alshugairi, 2010, p. 264) asked married American Muslims ( $n=333$ ) to identify reasons for conflict in their marriages. Over half the sample cited multiple reasons, but these results were not reported. Those who selected a single reason most often chose "other" (13.7\%), followed by "differences in life attitudes" (9.1\%), and "time spent with family" (7.7\%). A similar study conducted by an American Muslim media organization (Soundvision.com; Ghayyur, 2010) asked 405 divorced Muslims to cite their top three reasons for divorce. The most cited reason was incompatibility (25.71\% of participants), followed by abuse (13.12\%), disagreements over finances (10.41\%), interference from family and in-laws (10.20\%) and infidelity/adultery (8.79\%).

Neither of these studies presented findings on multiple sources of marital conflict, described the severity of conflict caused by each issue, or examined any particular source of conflict in detail. As they are the only studies as of this writing that examine sources of marital conflict in the community, more research is necessary to support and elaborate upon their findings.

\section{Extended Family as a Source of Conflict}

It is important to investigate sources of conflict that are of particular concern to the community itself. American Muslim community leaders commonly identify spouses' parents as an unique source of marital conflict for American Muslim couples (K. Iqbal, personal communication, October 17, 2008; Eid, 2005; Siddiqui, 2009). Alshugairi's and Soundvision's findings support the community leaders' observations.

Extended family generally tends to have a significant impact on the Muslim couple's life (e.g., Haddad et al., 2006). This role often begins with heavy involvement in the choice of spouse (Carolan, Bagherinia, Juhari, Himelright, \& Mouton-Sanders, 2000; Daneshpour, 1998; Haddad et al., 2006), and continues with practical assistance such as childcare and financial support, as well as marital conflict resolution, psychological support, advice, and companionship (Ahmad \& Reid, 2008; Carolan et al., 2000; Daneshpour, 1998; Eid, 2005; Goodwin \& Cramer, 2000).

This level of involvement can have positive or negative outcomes. In Macfarlane's (2012) qualitative study of 212 divorced American Muslims, some participants described their extended family's role in marital conflict resolution as helpful and supportive, but others wished they could have worked directly with each other without interference (Macfarlane, 2012). Similarly, other scholars within the Western Muslim community have recorded their observations of parents/in-laws' ability to disrupt the marriage by interfering with running of the home and raising of the children (Eid, 2005). As noted above, 10.2\% of Soundvision's sample chose "family or in-laws" as a top reason for divorce, while $7.7 \%$ of Alshugairi's sample chose "time spent with family" as a reason for conflict. Further, Sonuga-Barke, Mistry, and Qureshi (1998) found that British 
Muslim mothers who lived in a 3-generation family household had elevated rates of depression and anxiety as a function of intergenerational differences in attitudes about child-rearing.

Overall, the existing research suggests that extended family has a mixed effect on marital satisfaction. There is no detailed investigation of the average married American Muslim's extended family relationships that can describe when, how, and to what extent this relationship tends to be problematic. Given religious leaders' comments on the relevance of this topic to their community, empirical exploration into this aspect of American Muslim family life is still needed.

\section{The Present Study}

All told, there are few investigations of marital quality in the American Muslim community, though service providers and religious leaders need this information and the community itself has called for research (K. Iqbal, personal communication, October 17, 2008; Amer, 2010). Few studies attempt to establish whether American Muslim marriages are indeed at high risk of divorce as feared by community leaders. Two researchers provided conflicting divorce rates, and none describe the stability of currently intact marriages. The few studies on American Muslim marital quality tend to focus on marital satisfaction, and suggest that couples are generally satisfied but that women are less satisfied than men. More investigation is needed to establish these trends. Further, these studies neglect other indicators of marital quality, such as confidence in the marriage or quality of spousal interactions, and detailed information about marital conflict is rare. Empirical information about the influence of extended family on American Muslim marital health is particularly scarce, even though the community itself identifies extended family as an important factor in its marital health.

The present study responds to this gap in the literature by reporting upon the marital quality of a metropolitan American Muslim sample. It describes marriages in the community as a first step toward deeper exploration, and also as a source of information for religious leaders and service providers. In particular, this study asks the following questions:

1. What is the quality of participants' marriages, as measured by multiple indicators of marital quality?

2. What problems do participants report in their marriages?

a. To what extent are parents-in-law a problem in participants' marriages? 


\section{Method}

\section{Participants and Procedure}

\section{Recruitment}

A large local Muslim community organization requested this research and assisted with participant recruitment. Recruitment took place online between May 2009 and May 2010 via the email listservs of several Muslim community organizations. We collected data through an online survey platform, and offered participants a chance to enter a gift drawing in compensation for their time. Participants were eligible for the study if they were 18 or above, identified as Muslim, lived in America, were fluent in English, and were currently or formerly married. This article focuses on the currently married subset. We instructed participants that only one spouse per married couple should participate.

\section{Participants}

The final sample of currently married participants ( $n=296 ; 49.2 \%$ female) excluded 103 respondents who did not progress beyond demographic questions or did not meet eligibility criteria. Participants in the final sample tended to describe themselves as young, (57\% below 35 years; $56.3 \%$ in their first 10 years of marriage), highly-educated (nearly half had completed a graduate degree), and religious (averaging scores of $15, \mathrm{SD}=3$, on Haj-Yahia's measure of religiosity, described below). Most were South Asian (68.2\%) or part South Asian (2\%), long-term American residents (63.4\% residing in the US for over 20 years). Over half (56.1\%) lived in the state where the community organization is located. In general, participants reported that their spouses were similar to them on these demographic points. Table 1 offers further detail.

\section{Measures}

We chose the instruments in the present study from existing literature for their psychometric strength, brevity, and the applicability of their content to the American Muslim population. Several were successfully used in previous studies with non-American Muslim samples; however none were previously used in an American Muslim population. We adapted and added items as necessary to increase cultural appropriateness or to maintain consistent phrasing (e.g., we changed the word "partner" to "spouse" throughout all measures). 
TABLE 1. Demographics

\begin{tabular}{|c|c|}
\hline & Percentage of sample $(n)$ \\
\hline $\begin{array}{l}\text { Gender } \\
\text { Female }\end{array}$ & $49.2(145)$ \\
\hline $\begin{array}{l}\text { Age } \\
18-25 \\
26-35 \\
36-45 \\
46-55 \\
\geq 55\end{array}$ & $\begin{array}{l}9.2(27) \\
47.8(141) \\
18.6(55) \\
11.2(33) \\
13.3(39)\end{array}$ \\
\hline $\begin{array}{l}\text { Education }^{\mathrm{a}} \\
\text { High school } \\
\text { Undergrad } \\
\text { Graduate }\end{array}$ & $\begin{aligned} 3 & (9) \\
38 & (112) \\
59 & (174)\end{aligned}$ \\
\hline $\begin{array}{l}\text { Years in Ameri } \\
\quad<1-4 \\
5-9 \\
10-14 \\
15-19 \\
\geq 20\end{array}$ & $\begin{array}{l}6.5(19) \\
5.5(16) \\
11(32) \\
13.7(40) \\
63.4(185)\end{array}$ \\
\hline $\begin{array}{l}\text { Years married } \\
\qquad 1 \\
1-4 \\
5-9 \\
10-19 \\
20-39 \\
\geq 40\end{array}$ & $\begin{array}{c}8.9(24) \\
24.1(65) \\
23.3(63) \\
25.5(69) \\
15.6(43) \\
2.6(7)\end{array}$ \\
\hline $\begin{array}{l}\text { Religiosity } \\
\text { Range }=3-18\end{array}$ & $M=15, S D=3$ \\
\hline
\end{tabular}

\section{Descriptive Questions}

Descriptive questions included age, gender, education, presence of children below age 18 in the family, and religiosity. We measured the religiosity of our participants using a 3-item scale created by Haj-Yahia (2003). Scores ranged from 3 to 18 , with higher scores reflecting greater religiosity. In this study, the Cronbach's alpha of $\alpha=0.87$ was similar to the alpha obtained in Haj-Yahia's original study with an Arab Muslim sample.

\section{Measures of Marital Quality}

We chose multiple indices of marital quality in order to obtain a broad picture of the health and characteristics of participants' marriages. 


\section{Marital Satisfaction}

The 3-item Kansas Marital Satisfaction Scale (KMSS) created by Schumm et al. (1986) measured participants' marital satisfaction. Scores ranged from 3 to 21, with higher scores representing greater satisfaction. The scale is widely used, and performed well in a study with a Pakistani Muslim sample (Qadir et al., 2005). The Cronbach's alpha of $\alpha=0.98$ in this study resembles the alpha reported in Schumm and colleagues' (1986) original study as well in their recent use of the KMSS (Schumm, Crock, Likcani, Akagi, \& Bosch, 2008).

\section{Confidence in the Marriage}

This 4-item scale is a short form of a 10-item measure created by Stanley, Hoyer, and Trathen (1994; short form presented by Stanley, 2007). It measured participants' confidence that their marriages will last and successfully withstand difficulties. Scores ranged from 4 to 28 , with higher scores representing greater confidence. Cronbach's alpha for the short form in this study was $\alpha=0.96$, a higher internal reliability than studies that used the 10-item scale (Kline et al., 2004; Whitton et al., 2007).

\section{Marital Instability}

Booth, Johnson, and Edwards' (1983) widely-used 5-item Marital Instability Index measured the frequency of participants' thoughts and conversations about ending the marriage (i.e., "divorce proneness"). Scores ranged from 5 to 20, with higher scores representing greater instability. We adapted the index to include "Imam" and "family member" in the list of persons with whom divorce is discussed. Cronbach's alpha in this study was $\alpha=0.82$, higher than the reliability reported in the original study by Booth, Johnson and Edwards.

\section{Negative Interactions}

Stanley, Markman, and Whitton (2002) created this five-item scale to measure negative spousal interactions such as criticism and name-calling. Scores ranged from 5 to 15 ( $\alpha=0.81$ ) with higher scores representing greater levels of negative interactions. The internal reliability resembles those reported by Stanley and colleagues (2002).

\section{Positive Interactions}

Stanley, Markman, and Whitton (2002) created this three-item scale to measure positive interactions such as good conversations and satisfying sex. Stanley and colleagues included a fourth item measuring global marital satisfaction 
that was omitted in the present study. Scores ranged from 3 to 15 ( $\alpha=0.77$ ), with higher scores indicating more positive interactions. The internal reliability resembles those reported by Stanley and colleagues (2002).

\section{Problems in the Marriage}

\section{Problem List}

We based this 19-item list of problems upon a list of 17 relationship problems used by Peplau, Padesky, and Hamilton (1983) in their research on lesbian relationships. After consulting two experts in the American Muslim community, we added or changed several items to fit the American Muslim population. Participants read the list of issues that they and/or their spouses "may have had conflict about," and stated whether each was a minor, moderate, or major problem, or not a problem, in their relationship. Participants's scores on the problem list were summed in order to obtain a measure of problem severity. Scores ranged from 19 to 76 , with lower scores indicating that participants responded to most or all items as "not a problem [1]", and higher scores indicating that participants responded to most or all problems as "a major problem [4]." Cronbach's alpha for the problem severity scale was $\alpha=0.87$ in this study.

To derive a list of the top five problems for the overall sample as well as for demographic subsets (e.g., gender), we divided the total number of individuals recording each item as a moderate or major problem by the total sample $n$ to indicate the proportion of the sample that considered that item a moderate or major issue in their relationship.

\section{Discord with In-laws}

Bryant, Conger and Meehan (2001) developed this 3-item scale measuring happiness, conflict, and demands in the participant/parent-in-law relationship. We used two versions of Bryant, Conger and Meehan's scale in this study to measure discord experienced between self and each parent-in-law. Scores ranged from 3 to 12, with higher scores indicating more discord. We rephrased questions into present and past tense (e.g. "how happy are you (or were you) with your mother-in-law?") to include the possibility that the respondent's inlaws were deceased or otherwise absent from the respondent's life. Cronbach's alpha for the scale measuring discord with mothers-in-law was $\alpha=0.84$; for discord with fathers-in-law, it was $\alpha=0.79$. These reliabilities compare favorably with reliabilities reported in Bryant, Conger and Meehan's (2001) study. 


\section{Domestic Violence-Spouse and In-laws}

We used Sherin, Sinacore, Li, Zitter, and Shakil's (1998) 4-item HITS scale three times, to separately measure physical and psychological abuse perpetrated by the spouse, the mother-in-law, and the father-in-law. Scores ranged from 4 to 20, with higher scores indicating greater abuse. In this study, the Cronbach's alpha for spouse-focused HITS was $\alpha=0.80$, similar to the alpha reported in the original study. Mother-in-law-focused HITS was $\alpha=0.83$, and father-in-lawfocused HITS was $\alpha=0.52$.

\section{Data analysis}

We generated descriptive statistics for all items and/or scales in the study. Given the non-normality of the data, we used Spearman's rank order correlations to describe relationships among variables, and z-approximations of MannWhitney $U$ tests to examine differences in distributions across gender.

\section{Results}

\section{Marital Quality}

Participants reported high-quality marriages on measures of satisfaction, confidence, instability, and spousal interactions (see Table 2).

\section{Marital Satisfaction}

The median score for marital satisfaction (range $=3-21$, with 21 representing high satisfaction) was 18 for both men and women. Approximately two-thirds of the sample (64.7\%) scored at the top of the range, between 18 and 21. The distribution of satisfaction scores differed significantly across genders: men reported higher satisfaction on average $(z=-2.76, \mathrm{p}<0.01)$. Satisfaction also correlated positively with religiosity $(\rho(253)=.15, \mathrm{p}<.05)$ and negatively with the presence of minor children in the family $(\rho(177)=-.17, \mathrm{p}<.05)$. Table 3 presents Spearman's correlations between all variables.

\section{Marital Confidence}

The median score for marital confidence (range $=4-28$, with 28 representing high confidence) was 26 for the total sample ( 24 for women and 27 for men). Approximately two-thirds of the sample (62.2\%) scored at the top of the range, 
TABLE 2. Indicators of marital quality

\begin{tabular}{|c|c|c|c|c|}
\hline \multicolumn{2}{|c|}{ Total Sample } & Women & Men & Mann-Whitney $U$ test $^{\mathrm{a}}$ \\
\hline Marital Satisfaction & $17(5)$ & $16.02(5.09)$ ** & $17.55(4.16) * \star$ & \multirow[t]{5}{*}{-2.76} \\
\hline$($ range $=3-21)$ & 18 & 18 & 18 & \\
\hline$M(S D)$ & 255 & 129 & 25 & \\
\hline \multicolumn{4}{|l|}{$\mathrm{Md}$} & \\
\hline \multirow{2}{*}{\multicolumn{5}{|c|}{$\begin{array}{l}n \\
\text { Marital Confidence }\end{array}$}} \\
\hline Marital Confidence & $23(6)$ & & & \\
\hline (range=4-28) & 26 & 24 & 27 & \\
\hline$M(S D)$ & 233 & 119 & 114 & \\
\hline \multicolumn{5}{|l|}{ Md } \\
\hline \multicolumn{5}{|l|}{ Marital Instability } \\
\hline$($ range $=5-20)$ & $7(2)$ & $6.77(2.11)$ & $6.33(1.80)$ & \\
\hline$M(S D)$ & 6 & 6 & 6 & \\
\hline \multicolumn{4}{|l|}{$n$} & \\
\hline Positive interactions & $11(3)$ & $11.46(2.72)$ & $11.32(2.76)$ & \\
\hline$($ range=3-15) & 12 & 12 & 12 & \\
\hline$M(S D)$ & 218 & 112 & 106 & \\
\hline \multicolumn{5}{|l|}{$\mathrm{Md}$} \\
\hline \multicolumn{5}{|l|}{$n$} \\
\hline Negative interactions & $8(3)$ & $8.50(2.68)$ & $8.18(2.49)$ & \\
\hline$($ range $=5-15)$ & 8 & 8 & 8 & \\
\hline$M(S D)$ & 223 & 114 & 109 & \\
\hline \multicolumn{5}{|l|}{$\mathrm{Md}$} \\
\hline \multicolumn{5}{|l|}{$n$} \\
\hline \multicolumn{5}{|l|}{ Domestic violence } \\
\hline$($ range $=4-20)$ & $6(3)$ & $5.97(3.07)$ & $5.68(2.32)$ & \\
\hline$M(S D)$ & 5 & 5 & 5 & \\
\hline Md & 226 & 116 & 110 & \\
\hline$n$ & & & & \\
\hline
\end{tabular}

Notes: Varying sample sizes reflect missing data.

aScores are z-approximations of the Mann-Whitney $U$

Asterisks indicate significant differences across gender: ${ }^{\star} p<0.05 ;{ }^{*} p<0.01$

between 24 and 28. Marital confidence distributions also differed significantly by gender: men reported higher confidence on average $(z=-2.36, \mathrm{p}<.05)$. Confidence correlated positively with age $(\rho(231)=.15, \mathrm{p}<.05)$, education $(\rho(231)$ $=.14, \mathrm{p}<.05)$, and religiosity $(\rho(231)=.16, \mathrm{p}<.05)$.

\section{Marital Instability}

Marital instability (range $=5-20$, with 20 representing high instability) was low, with a median score of 6 for both men and women. Approximately two-thirds of the sample (64.9\%) scored at the bottom of the range, between 5 and 6. Marital instability correlated positively with the presence of minor children in the family $(\rho(138)=.24, \mathrm{p}<.01)$. 


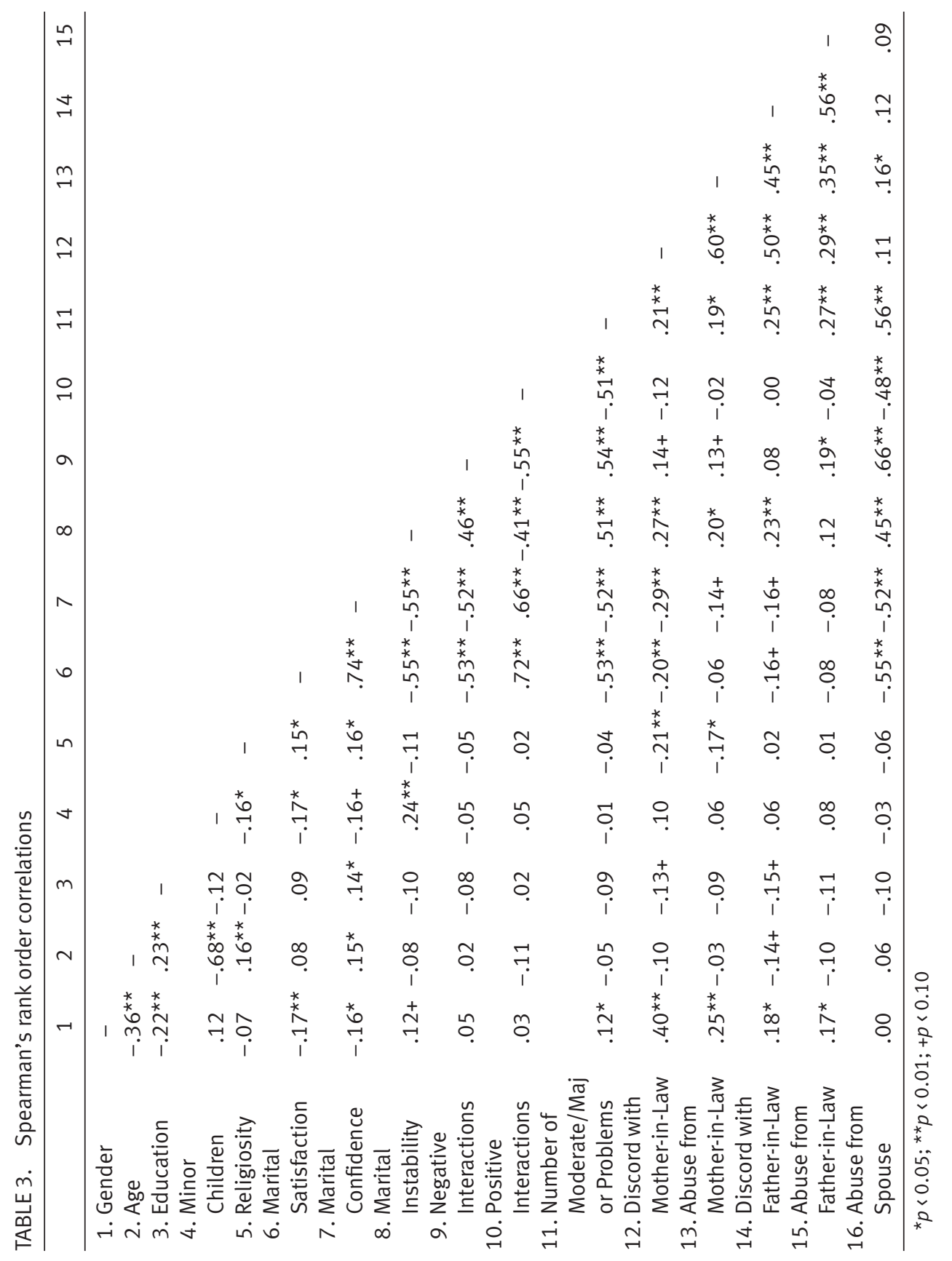




\section{Spousal Interactions}

The median score for positive interactions (range $=3-15$, with 15 indicating more positive interactions) was 12 for both men and women. Approximately two-thirds of the sample (66.5\%) scored between 11 and 15 . The median score for negative interactions (range $=5-15$, with 15 indicating more negative interactions) was 8 for both men and women; two-thirds of the sample (68.2\%) scored between 5 and 9 .

Problems in the Marriage

\section{Problem List}

Almost half of the sample (43.9\%) reported that all 19 items in the problem list were not problems, or were minor problems in their relationship. The rest (56.1\%) stated that at least one problem was a moderate or major issue in their relationship $(\mathrm{M}=2.29, \mathrm{SD}=3.13)$. Specifically, $11.5 \%$ endorsed one problem, $8.8 \%$ endorsed two, $8.8 \%$ endorsed three, $8.4 \%$ endorsed four, and $6.8 \%$ endorsed five items out of 19 as moderate or major issues.

On average, women endorsed more items as "moderate" or "major" problems in their relationship than did men $(z=-2.05, \mathrm{p}<0.05)$, though there was no gender difference in endorsement of "minor" problems, or in the total severity of problems. Gender differences also occurred in response to particular problems. Women were more likely on average to endorse "finances" $(z=-2.55$, $\mathrm{p}<.05)$, "differences in culture of origin" $(z=-2.81, \mathrm{p}<.01)$ and "in-laws" (discussed below) as problems in their relationship, while men were more likely on average to endorse "my spouse's desire to be independent" $(z=-3.14, \mathrm{p}<.01)$ as a problem.

In order to obtain an understanding of the most important problems for couples in the sample, we ranked problems according to the proportion of the sample that reported the item as a moderate or a major problem in their marriage. The top five problems reported in the overall sample, as well as in different sample subsets, are reported in Table 4. "In-laws" and "Different Interests" appeared in the top three problems for every sample subset.

\section{Domestic Violence}

Participants rarely reported that their spouse perpetrated physical and psychological domestic violence (Table 2). The median score on the HITS scale (range $=4-20$, with 20 indicating high violence) was 5 for both men and women, and two-thirds of the sample (63.7\%) scored at the bottom of the range, between 4 and 5. Domestic violence was unrelated to any demographic variable; however, 
TABLE 4. Top five "moderate or major" problems

\begin{tabular}{|c|c|c|c|c|c|}
\hline & Total Sample & Women & Men & $\begin{array}{l}\text { Low Marital } \\
\text { Satisfaction }\end{array}$ & $\begin{array}{l}\text { High Marital } \\
\text { Satisfaction }\end{array}$ \\
\hline Problem 1 & In-laws (29.7) & In-laws (36) & $\begin{array}{c}\text { Different } \\
\text { Interests (26.1) }\end{array}$ & $\begin{array}{c}\text { Different } \\
\text { interests }(64.7)\end{array}$ & In-Laws (25.8) \\
\hline Problem 2 & $\begin{array}{c}\text { Different } \\
\text { interests }(26.7)\end{array}$ & $\begin{array}{c}\text { Finances } \\
(29.6)\end{array}$ & $\begin{array}{l}\text { In-laws } \\
(22.8)\end{array}$ & $\begin{array}{l}\text { Spending time } \\
\text { together (55.9) }\end{array}$ & $\begin{array}{c}\text { Different } \\
\text { Interests }(20.4)\end{array}$ \\
\hline Problem 3 & Finances (24.7) & $\begin{array}{c}\text { Different } \\
\text { interests } \\
(27.2)\end{array}$ & $\begin{array}{l}\text { Attitudes } \\
\text { toward } \\
\operatorname{sex}(22.6)\end{array}$ & In-laws (53) & $\begin{array}{l}\text { Attitudes } \\
\text { toward } \\
\text { sex }(17.4)\end{array}$ \\
\hline Problem 4 & $\begin{array}{l}\text { Attitudes } \\
\text { toward } \\
\text { sex }(21.2)\end{array}$ & $\begin{array}{l}\text { Spending time } \\
\text { together }(22.2)\end{array}$ & $\begin{array}{c}\text { Finances } \\
(19.3)\end{array}$ & $\begin{array}{c}\text { Religious } \\
\text { Differences } \\
\quad(50)\end{array}$ & $\begin{array}{c}\text { Family or } \\
\text { Friends (14.2) }\end{array}$ \\
\hline Problem 5 & $\begin{array}{l}\text { Family or } \\
\text { friends (18) }\end{array}$ & $\begin{array}{l}\text { Family or } \\
\text { friends (21) }\end{array}$ & $\begin{array}{c}\text { Family or } \\
\text { friends (14.9) }\end{array}$ & $\begin{array}{l}\text { Attitudes } \\
\text { toward } \\
\text { sex }(44.1)\end{array}$ & $\begin{array}{l}\text { Household } \\
\text { tasks (12.6) }\end{array}$ \\
\hline$n$ & $238-241$ & $124-126$ & $114-115$ & 34 & $204-207$ \\
\hline
\end{tabular}

it related strongly and in the predicted directions with other indices of marital quality, such that reports of higher domestic violence were correlated with lower marital quality.

\section{In-laws}

Participants endorsed little to no verbal or physical abuse or discord with each parent-in-law (Table 5). The median score on the HITS scales for both in-laws (range $=4-20$, with 20 indicating high violence) was 4 for both men and women; $72.7 \%$ of the sample obtained the lowest possible score on the scale (4) for mother-in-law abuse; for father-in-law abuse, this percentage was $81.8 \%$ of the sample. The median score for the mother-in-law discord scale (range $=3-12$, with 12 indicating greater discord) was 6 for women and 4 for men, and twothirds of the sample (62.6\%) scored at the bottom of the scale, between 3 and 5. The median score for the father-in-law discord scale was 4 for both men and women, and two-thirds of the sample (62.8\%) scored at the bottom of the scale, between 3 and 4 .

Despite these low reports of discord and abuse, however, participants consistently ranked "in-laws" among the top three problem domains (see Table 4). Women tended to rate in-laws as a more severe problem in their relationship $(z=-2.50, \mathrm{p}<.05)$, with a median score of 2 out of 4 on the scale of problem severity, compared to men's score of 1 out of 4 (Table 5). Distributions also dif- 
TABLE 5. Interactions with In-laws

\begin{tabular}{|c|c|c|c|c|}
\hline & Total Sample & Women & Men & Mann-Whitney $U^{a}$ \\
\hline \multicolumn{5}{|l|}{ "In-laws” } \\
\hline (range=1-4) & $2(1.10)$ & $2.18 *(1.16)$ & $1.80 *(0.99)$ & -2.50 \\
\hline M (SD) & 2 & 2 & 1 & \\
\hline $\mathrm{Md}$ & 239 & 125 & 114 & \\
\hline$n$ & & & & \\
\hline \multicolumn{5}{|l|}{ Mother-in-Law } \\
\hline Abuse (range $=4-20)$ & $4.79(2.11)$ & $4.99 * \star(2.02)$ & $4.57^{\star \star}(2.18)$ & -3.33 \\
\hline$M(S D)$ & 4 & 4 & 4 & \\
\hline $\mathrm{Md}$ & 183 & 94 & 89 & \\
\hline \multicolumn{5}{|l|}{$n$} \\
\hline Discord (range $=3-12)$ & $5.30(2.37)$ & $6.06^{\star \star}(2.41)$ & $4.45^{\star \star}(2.03)$ & -5.28 \\
\hline$M(S D)$ & 5 & 6 & 4 & \\
\hline Md & 179 & 94 & 85 & \\
\hline$n$ & & & & \\
\hline \multicolumn{5}{|l|}{ Father-in-Law } \\
\hline Abuse (range $=4-20)$ & $4.41(1.13$ & $4.50 *(1.11)$ & $4.31 *(1.15)$ & -2.22 \\
\hline$M(S D)$ & 4 & 4 & 4 & \\
\hline Md & 165 & 84 & 81 & \\
\hline \multicolumn{5}{|l|}{$n$} \\
\hline Discord (range $=3-12)$ & $4.59(1.98)$ & $4.82 *(1.94)$ & $4.36 *(2.02)$ & -2.13 \\
\hline$M(S D)$ & 4 & 4 & 4 & \\
\hline $\mathrm{Md}$ & 145 & 73 & 72 & \\
\hline$n$ & & & & \\
\hline
\end{tabular}

Note: Asterisks indicate significant differences across gender: ${ }^{\star} p<0.05 ;{ }^{\star \star} p<0.01$.

Varying sample sizes reflect missing data.

aScores are z-approximations of the Mann-Whitney $U$

bSeverity ranges from 1-4, with 1 reflecting "not a problem" and 4 reflecting "a major problem".

fered significantly on reports of abuse and discord from in-laws: women were more likely on average than men to report abuse and discord from both in-laws (mother-in-law abuse: $z=-3.33, \mathrm{p}<.01$; mother-in-law discord: $z=-5.28, \mathrm{p}<$ .01 ; father-in-law abuse: $z=-2.22, \mathrm{p}<.05$; father-in-law discord: $z=-2.13, \mathrm{p}<$ .05 ; see Table 5 ).

\section{Discussion}

This study described the quality of the marriages of 296 American Muslim adults. The sample was concentrated in one major metropolitan area of the United States, but included individuals from across the United States and Canada. Most participants were young, religious, well-educated, long-term American residents of South Asian heritage. 


\section{Marital Quality}

Participants reported high global marital satisfaction and strong confidence in their marriages. Spousal interactions were generally positive. Participants endorsed few moderate or major relationship problems, and rarely reported marital instability and domestic violence. Satisfaction and confidence positively correlated with religiosity, and satisfaction and stability negatively correlated with the presence of minor children in the home. Overall, the sample reported excellent marital quality, a finding that may help to allay some of the community's fears about its members' marital health.

This pattern of high marital quality compares well with research on other religious Americans. For example, participants' high satisfaction (KMSS) scores resemble those of 178 religious couples in a study by DeMaris, Mahoney and Pargament (2010); 71 religious couples within their first ten years of marriage in a study by Bowman and Sutton (2004); and 169 newly-wed couples in a study by Neff and Karney (2009). It is also common for couples with minor children to report lower marital quality than couples with no children or older children (Bradbury, Fincham, \& Beach, 2000; Kamp Dush et al., 2008).

However, the highly positive results may also reflect some bias on the part of participants toward presenting their marriages in a positive light. Positive response bias is natural in research of this kind, but it may occur to a unique level for American Muslims in response to community and societal pressures. For example, Muslims place a particularly high value on marriage, and participants may have felt pressured to appear maritally healthy if their local community stigmatizes divorce and marital discord. The American Muslim community is also beleaguered from without by stigma and misconceptions about Islam; participants may experience this stigma and lack of understanding as pressure to represent their religion and community as positively as possible in order to protect their community's image. Readers should therefore consider this study's results with these points in mind.

\section{Gender Differences in Marital Quality}

An important finding of this study is that women's marital satisfaction and marital confidence, although high, were significantly lower than men's. Women were also more likely than men to report that relationship issues were moderate or major problems as opposed to minor problems. This finding suggests that women experienced somewhat lower marital quality than men, a pattern that mirrors previous research on American Muslims (Alshugairi, 2010; Asamarai et al., 2008) and prevails in research on the general American public (e.g., Amato et al., 2003; Corra et al., 2009; Kamp Dush et al., 2008). The pat- 
tern is typically attributed to women's lower level of influence in the relationship and their greater burden of housework and childcare (Amato et al., 2003; Steil, 2000). It is essential to explore the role that these factors (collectively known as marital power) play in American Muslim marriages, particularly because American cultural norms espousing gender equality may conflict with traditional/conservative interpretations of Islam that favor husband-dominant marital relationships. Given a population that is both religious and highly acclimated to American culture, American Muslim spouses may experience internal and dyadic conflict about gender roles in their relationship depending on how they interpret religious teachings regarding gender. There may also be gender differences in attitudes toward gender roles (as in research on the general American public): in tentative support of this gender difference, the present study found that men were more likely than women to say that "my spouse's desire to be independent" was a problem in their relationship.

\section{The Effect of In-laws and Other Family on Marital Quality}

This study's examination of the role of extended family yielded interesting results. Participants rarely reported physical and psychological abuse from inlaws or discord with in-laws. Yet, "in-laws" were consistently ranked among the top three relationship problems in the sample, across gender and levels of marital satisfaction. "Family and friends" also recurred in the top five among almost all groups (see Table 3). Further, although reports of abuse and discord with in-laws were low, those who reported it tended to be women.

Family and in-laws can cause problems for couples regardless of religious affiliation: for example, Miller et al.s (2003) samples of couples seeking therapy reported in-laws as third in their top five problems when they were within their first three years of marriage, and Storaasli and Markman (1990) found that "relatives" ranked third for 40 non-distressed couples at early marriage. However, Miller's couples did not rank in-laws in the top five problems after the first three years of marriage, and "relatives" dropped to the fourth rank for Storaasli and Markman's couples at early parenting. This pattern was not evident in the present American Muslim sample, in which the reported severity of problems with in-laws did not relate to age or number of years married. Rather, the pattern of data in this study suggests that many married Muslims experience manageable but noticeable problems with in-laws that do not generally involve discord or abuse but some other type of negative experience. This problem does not appear to diminish with time.

\section{Limitations}

Several limitations in this study require attention. First, the data in the study was considerably skewed towards positive marital quality, and the above-noted 
patterns in the data (e.g., gender differences) should be considered in light of this skew. It is quite possible that the skew reflects a combination of happy participants and positive response bias.

Second, the data from this study were part of a larger survey that many participants failed to complete due to its length. A shorter survey may have reduced the chance of response bias or otherwise improved the quality of the data.

Third, and perhaps most significantly, this project was undertaken at the request and with the support of a large American Muslim community organization, which assisted energetically with advertising and participant recruitment. The majority of the sample lived in the geographic area surrounding this organization. We made every effort to publicize the fact that participants' responses were confidential and could not be traced to their identity. Regardless, it is quite likely that participants recruited from the organization's locality felt uneasy about reporting marital distress in a setting that appeared so closely tied to their social and religious community.

\section{Implications for Research}

This study is a first step toward a comprehensive examination of American Muslim marriages. Future research should attempt to replicate the findings of this survey, as there are few studies on the married American Muslim population and the emerging trends therefore require support and clarification.

For example, further investigation of gender differences in American Muslim marital quality will help to establish whether women consistently appear less happy than men. Studies should also investigate why this may be the case. Studies on non-Muslim Americans often conclude that the gender trend reflects differences in marital power-typically that women have less power than men. Is this power difference true for American Muslims? What role does Muslim couples' religious identification play in their marital power distribution? Islam can be, and has been, interpreted in favor of gender equality as well as traditional gender roles; it would be interesting and important to examine the effect of American Muslims' religious interpretations on their distribution of family roles.

Another topic for future research is the role of extended family in general, and in-laws in particular, on American Muslim couples' lives. How are extended family members involved in couples' lives? Why are in-laws a top problem despite very few reports of abuse and discord? Why particularly for women? Sonuga-Barke and colleagues (1998) suggest that differences in attitudes create conflict in British Muslim families, chiefly for women, and particularly when multiple generations live in the same house and raise children together. Does this explanation apply to American Muslims? Is it also generally true that a certain level of geographic proximity is required before in-laws become a signifi- 
cant problem in American Muslim marriages, as Sonuga-Barke and colleagues' study suggests?

\section{Implications for Practice}

In addition to suggesting avenues for further empirical investigation, several findings in the present study may inform the practice of mental health service providers who work with American Muslim clients. Based on these findings, a list of recommendations follows.

Service providers who work with American Muslims experiencing marital discord should be aware that wives may report more marital distress than husbands. Their distress may include greater dissatisfaction with the marriage, less confidence in the marriage, identification of more marital problems, and more frequent thoughts about ending the marriage. There is not yet enough research on American Muslim marriages to explain wives' greater dissatisfaction. This study suggests that independence may be one issue.

Service providers should note the life stage of the distressed couple. Spouses with minor children are more likely to report marital distress than those with no children or adult children. In such cases, case management may be helpful in assisting the couple to find practical solutions to childcare and other issues unique to bringing up their family.

Service providers should enquire about the role that parents-in-law may play in their American Muslim clients' distress. Providers should assess the level of spouses' parents' involvement in the daily life of the couple and the extent of generational differences in such areas as child-rearing and gender roles. The impact of parents-in-law may be particularly salient for women: though there were few reports of discord with in-laws and abuse from in-laws, those who reported these experiences tended to be women. Particular sensitivity should be employed in cases in which parents-in-law contribute to marital distress, in order to avoid alienating the spouse who is the child of the parents-in-law.

Although reports of verbal and physical abuse were low among the Muslims sampled, they did occur, and should be screened and promptly addressed. Islamic text has often been interpreted to condone varying extents of husbandon-wife violence, though American Muslim leaders commonly reject this interpretation as mistaken and highly damaging to families and community.

Overall, service providers should remain acutely aware of the potential that their Muslim clients are underreporting marital issues that are perceived as private or shameful. For example, although this study found that religiosity was related to high marital satisfaction, this relationship does not necessarily indicate that religious individuals do not experience marital distress. It is quite possible that highly religious Muslims experience greater shame, guilt, fear, or social stigma related to marital distress than do less religious Muslims. This 
experience would affect their ability and willingness to seek services for these concerns. Skilled and respectful questioning combined with a non-judgmental, compassionate attitude may elicit greater disclosure in such cases. In particular, service providers might bear in mind that divorce may not be an acceptable option for Muslim clients. Muslim clients may fear that professionals will encourage them to end their marriages, and may feel reluctant to discuss their marital concerns for this reason.

\section{Conclusion}

Studies of American Muslim marital quality are integral to the growing effort to gain deeper understanding of the characteristics, strengths, and problem areas of the American Muslim community. The American Muslim community currently knows little about the health of its members' marriages; yet, it greatly values marriage, and research strongly supports the positive influence of healthy marriages on countless aspects of individual and social health and well-being. The results of this study suggest that American Muslims generally report satisfying and healthy marriages, but that women experience lowerquality marriages than men. Results suggest that in-laws do cause problems for some American Muslim spouses, particularly for wives. Future research should further examine the gender trends identified in this study and obtain more information regarding the impact of the extended family network on the dyadic relationship.

\section{References}

Abu-Ras, W., Gheith, A., \& Cournos, F. (2008). The Imam's Role in Mental Health Promotion: A Study at 22 Mosques in New York City's Muslim Community. Journal of Muslim Mental Health, 3(2), 155-176. http://dx.doi.org/10.1080/15564900802487576

Ahmad, S., \& Reid, D. W. (2008). Relationship Satisfaction among South Asian Canadians: The Role of "Complementary-Equality"and Listening to Understand. Interpersona, Special Issue: Relationship Research in India and South Asia, 2(2), $131-150$.

Ahmed, S., \& Reddy, L. A. (2007). Understanding the Mental Health Needs of American Muslims: Recommendations and Considerations for Practice. Journal of Multicultural Counseling and Development, 35(4), 207. http://dx.doi.org/10.1002/j.21611912.2007.tb00061.x

Ali, O. M., Milstein, G., \& Marzuk, P. M. (2005). The Imam's Role in Meeting the Counseling Needs of Muslim Communities in the United States. Psychiatric Services, 56(2), 202-205. http://dx.doi.org/10.1176/appi.ps.56.2.202

Alshugairi, N. (2010). Marital Trends in the American Muslim Community: A Pilot Study. Journal of Muslim Mental Health, 5(3), 256. http://dx.doi.org/10.1080/1556 4908.2010.551275 
Amato, P. R., Johnson, D. R., Booth, A., \& Rogers, S. J. (2003). Continuity and Change in Marital Quality Between 1980 and 2000. Journal of Marriage and Family, 65(1), 1-22. http://dx.doi.org/10.1111/j.1741-3737.2003.00001.x

Amer, M. M. (2010). Editor's Introduction: Rumor versus Research: Publishing Empirical Mental Health Evidence Related to Common Community Concerns. Journal of Muslim Mental Health, 5(3), 249. http://dx.doi.org/10.1080/15564908.2010 .556547

Asamarai, L. A., Solberg, K. B., \& Solon, P. C. (2008). The role of religiosity in Muslim spouse selection and its influence on marital satisfaction. Journal of Muslim Mental Health, 3(1), 37-52. http://dx.doi.org/10.1080/15564900802006459

Bagby, I. A. W., Perl, P. M., \& Froehle, B. (2001). The Mosque in America, a National Portrait: A Report from the Mosque Study Project. Washington, D.C.: Council on American-Islamic Relations.

Ba-Yunus, I. (2000, August). Divorce Among Muslims. Islamic Horizons.

Ba-Yunus, I. (2007). How do Muslims in North America Divorce? In M. Akhtar (Ed.), Muslim family in a dilemma: quest for a western identity (pp. 9-18). University Press of America.

Beverley, J. A. (2002). Islamic faith in America. Infobase Publishing.

Booth, A., Johnson, D., \& Edwards, J. N. (1983). Measuring Marital Instability. Journal of Marriage \& Family, 45(2), 387. http://dx.doi.org/10.2307/351516

Bowman, A. D., \& Sutton, G. W. (2004). Marital satisfaction and relational attachment in a sample of newly married couples. Psychological reports, 95(3), 989-991. http:// dx.doi.org/10.2466/pro.95.3.989-991

Bradbury, T. N., Fincham, F. D., \& Beach, S. R. . (2000). Research on the nature and determinants of marital satisfaction: A decade in review. Journal of Marriage and Family, 62(4), 964-980. http://dx.doi.org/10.1111/j.1741-3737.2000.00964.x

Bramlett, M. D., \& Mosher, W. D. (2002). Cohabitation, marriage, divorce, and remarriage in the United States (Vital and Health Statistics, Series 23, No. 22). Hyattsville, MD: National Center for Health Statistics.

Bryant, C. M., Conger, R. D., \& Meehan, J. M. (2001). The Influence of In-Laws on Change in Marital Success.

Bukhari, Z. H. (2003). Demography, identity, space: defining American Muslims. (P. Strum \& D. Tarantolo, Eds.) Muslims in the United States. Washington, DC: Woodrow Wilson International Center for Scholars, 7-21.

Bulanda, J. R. (2011). Gender, Marital Power, and Marital Quality in Later Life. Journal of Women \& Aging, 23(1), 3-22. http://dx.doi.org/10.1080/08952841.2011.540481

Carolan, M. T., Bagherinia, G., Juhari, R., Himelright, J., \& Mouton-Sanders, M. (2000). Contemporary Muslim families: Research and practice. Contemporary Family Therapy, 22(1), 67-79. http://dx.doi.org/10.1023/A:1007770532624

Carrere, S., Buehlman, K. T., Gottman, J. M., Coan, J. A., \& Ruckstuhl, L. (2000). Predicting marital stability and divorce in newlywed couples. Journal of Family Psychology, 14(1), 42-58. http://dx.doi.org/10.1037/0893-3200.14.1.42

Corra, M., Carter, S. K., Carter, J. S., \& Knox, D. (2009). Trends in Marital Happiness by Gender and Race, 1973 to 2006. Journal of Family Issues, 30(10), $1379-1404$. http://dx.doi.org/10.1177/0192513X09336214

Curtis, E. E. (2010). Encyclopedia of Muslim-American History. Infobase Publishing.

Daneshpour, M. (1998). Muslim families and family therapy. Journal of Marital and Family Therapy, 24(3), 355-368. http://dx.doi.org/10.1111/j.1752-0606.1998. tb01090.x 
DeMaris, A., Mahoney, A., \& Pargament, K. I. (2010). Sanctification of Marriage and General Religiousness as Buffers of the Effects of Marital Inequity. Journal of Family Issues, 0192513X10363888. http://dx.doi.org/10.1177/0192513X10363888

Eid, T. (2005). Marriage, divorce, and child custody as experienced by American Muslims: Religious, social, and legal considerations. Harvard Divinity School, United States -- Massachusetts.

Ghayyur, T. (2010, July 22). Divorce in the Muslim Community: 2010 Survey Analysis. SoundVision.com. Retrieved February 16, 2011, from http://www.soundvision. com/info/marriage/conflict/muslimdivorcesurvey2010.asp

Goodwin, R., \& Cramer, D. (2000). Marriage and social support in a BritishAsian community. Journal of Community \& Applied Social Psychology, 10(1), 49-62. http://dx.doi.org/10.1002/(SICI)1099-1298(200001/02)10:1<49::aidcasp549>3.0.CO;2-0

Haddad, Y. Y., Smith, J. I., \& Moore, K. M. (2006). Muslim women in America: the challenge of Islamic identity today. Oxford University Press US. http://dx.doi. org/10.1093/acprof:oso/9780195177831.001.0001

Haj-Yahia, M. M. (2003). Beliefs About Wife Beating Among Arab Men from Israel: The Influence of Their Patriarchal Ideology. Journal of Family Violence, 18(4), 193 206. http://dx.doi.org/10.1023/A:1024012229984

Haque, A., \& Davenport, B. (2009). The Assessment of Marital Adjustment with Muslim Populations: A Reliability Study of the Locke-Wallace Marital Adjustment Test. Contemporary Family Therapy, 31(2), 160-168. http://dx.doi.org/10.1007/ s10591-009-9087-5

Hodge, D. R. (2005). Social work and the house of Islam: Orienting practitioners to the beliefs and values of Muslims in the United States. Social Work, 50(2), 162-173. http://dx.doi.org/10.1093/sw/50.2.162

Kamp Dush, C. M., Taylor, M. G., \& Kroeger, R. A. (2008). Marital Happiness and Psychological Well-Being Across the Life Course*. Family Relations, 57(2), 211-226. http://dx.doi.org/10.1111/j.1741-3729.2008.00495.x

Kholoki, S. (2007, February 4). Alarming divorce rates amongst Muslims! Southern California InFocus. Retrieved from http://www.infocusnews.net/content/ view/986/135

Kline, G. H., Stanley, S. M., Markman, H. J., Olmos-Gallo, P. A., St Peters, M., Whitton, S. W., \& Prado, L. M. (2004). Timing Is Everything: Pre-Engagement Cohabitation and Increased Risk for Poor Marital Outcomes. Journal of Family Psychology, 18(2), 311. http://dx.doi.org/10.1037/0893-3200.18.2.311

Leonard, K. I. (2003). Muslims in the United States: the state of research. Russell Sage Foundation.

Macfarlane, J. (2012). Understanding Trends in American Muslim Divorce and Marriage: A Discussion Guide for Families and Communities. Institute for Social Policy and Understanding. Retrieved from http://ispu.org/GetReports/35/2399/Publications.aspx

Miller, R. B., Yorgason, J. B., Sandberg, J. G., \& White, M. B. (2003). Problems That Couples Bring To Therapy: A View Across the Family Life Cycle. The American Journal of Family Therapy, 31(5), 395. http://dx.doi.org/10.1080/01926180390223950

Nadir, A. (1998). Promoting Positive Marital Outcomes Among Muslims in America. In C. Lan (Ed.), Islam in America: images and challenges (pp. 127-139). University of Indianapolis Press.

Neff, L. A., \& Karney, B. R. (2009). Stress and reactivity to daily relationship experi- 
ences: How stress hinders adaptive processes in marriage. Journal of personality and social psychology, 97(3), 435-450. http://dx.doi.org/10.1037/a0015663

Peplau, L. A., Padesky, C., \& Hamilton, M. (1983). Satisfaction in lesbian relationships. Journal of Homosexuality, 8(2), 23-35. http://dx.doi.org/10.1300/J082v08n02_04

Qadir, F., de Silva, P., Prince, M., \& Khan, M. (2005). Marital satisfaction in Pakistan: A pilot investigation. Sexual and Relationship Therapy, 20(2), 195-209. http://dx.doi. org/10.1080/14681990500113260

Schumm, W. R., Crock, R. J., Likcani, A., Akagi, C. G., \& Bosch, K. R. (2008). Reliability and validity of the Kansas Marital Satisfaction Scale with different response formats in a recent sample of US Army personnel. Individual Differences Research. http://dx.doi.org/10.2307/352405

Schumm, W. R., Paff-Bergen, L. A., Hatch, R. C., Obiorah, F. C., Copeland, J. M., Meens, L. D., \& Bugaighis, M. A. (1986). Concurrent and Discriminant Validity of the Kansas Marital Satisfaction Scale. Journal of Marriage \& Family, 48(2), 381.

Shah, N. (2007). Religiosity and marital satisfaction among Muslims. California State University, Long Beach.

Sherin, K. M., Sinacore, J. M., Li, X. Q., Zitter, R. E., \& Shakil, A. (1998). HITS: a short domestic violence screening tool for use in a family practice setting. Family Medicine, 30(7), 508-512.

Siddiqui, S. (2009, August 6). Divorce among American Muslims: Statistics, Challenges \& Solutions. SoundVision.com. Retrieved February 16, 2011, from http://www. soundvision.com/info/marriage/conflict/muslimdivorcestats.asp

Sonuga-Barke, E. J. ., Mistry, M., \& Qureshi, S. (1998). The mental health of Muslim mothers in extended families living in Britain: The impact of intergenerational disagreement on anxiety and depression. British journal of clinical psychology, 37(4), 399-408. http://dx.doi.org/10.1111/j.2044-8260.1998.tb01397.x

Stanley, S. M. (2007). Assessing couple and marital relationships: Beyond form and toward a deeper knowledge of function. Handbook of measurement issues in family research, 85-99.

Stanley, S. M., Hoyer, L., \& Trathen, D. W. (1994). The confidence scale. Unpublished manuscript, University of Denver, Denver, CO.

Stanley, S. M., Markman, H. J., \& Whitton, S. W. (2002). Communication, conflict, and commitment: Insights on the foundations of relationship success from a national survey. Family Process, 41(4), 659-675. http://dx.doi.org/10.1111/j.1545-5300.2002.00659.x

Steil, J. M. (2000). Contemporary marriage: Still an unequal partnership. In C. Hendrick \& S. S. Hendrick (Eds.), Close Relationships: A Sourcebook (pp. 125-136). Thousand Oaks, CA, US: Sage Publications, Inc. http://dx.doi.org/10.4135/9781452220437.n10

Storaasli, R. D., \& Markman, H. J. (1990). Relationship Problems in the Early Stages of Marriage:: A Longitudinal Investigation. Journal of Family Psychology, 4(1), 80-98. http://dx.doi.org/10.1037/0893-3200.4.1.80

Waite, L. J. (2003). Why marriage matters. Points \& counterpoints: Controversial relationship and family issues in the 21st century (an anthology). (pp. 64-69). Los Angeles, CA, US: Roxbury Publishing Co.

Whitton, S. W., Olmos-Gallo, P. A., Stanley, S. M., Prado, L. M., Kline, G. H., St. Peters, M., \& Markman, H. J. (2007). Depressive symptoms in early marriage: Predictions from relationship confidence and negative marital interaction. Journal of Family Psychology, 21(2), 297-306. http://dx.doi.org/10.1037/0893-3200.21.2.297 